\title{
ANALYTICAL MODELLING OF SEAKEEPING QUALITIES OF CONTAINER VESSEL
}

\section{АНАЛІТИЧНЕ МОДЕЛЮВАННЯ МОРЕХІДНИХ ЯКОСТЕЙ КОНТЕЙНЕРОВОЗУ}

\author{
N. M. Konon, assistant \\ Н. М. Конон, асистент \\ National University «Odessa Maritime Academy», Ukraine \\ Наџіональний університет «Одеська Морська Академія», Україна
}

\begin{abstract}
The design of ships or any other floating systems intended to operate on or close to the surface of the sea is controlled to a large extent by what is usually referred to as seakeeping, or, in more common terminology, safety at sea. This is a primary consideration and criteria, which has to be fully met. Safety of a ship naturally includes the crew, cargo and the hull itself. Seakeeping is, indeed, a generalized term and reflects the ship's capability to survive all hazards at sea such as collision, grounding, fire, as well as heavy-weather effects related to the environment in general and waves in particular. The two most likely types of failure under these conditions are due to structural causes and capsizing resulting from insufficient stability under severe weather conditions.

Such criteria as economical navigation of the ship as related to speed-keeping abilities, fuel consumption, avoidance of damage to ship components and cargo, and comfort to crew or passengers, or both, are key items. The operational limits of electronic equipment, mechanical components and weapon systems on board warships are other aspects of sea keeping.

In this work it is highlighted that seakeeping is a generalized term that includes a wide variety of subjects such as ship motions (amplitudes, accelerations, phases), deck wetness, slamming, steering in waves, added resistance, hydrodynamic loadings (pressures, forces, moments) and transient loads. Since the ship environmental operability or its sea keeping characteristics are closely linked to the severity of the sea, the description of the seaway is usually considered as an integral part of sea keeping.

It is taken into consideration that the severity of the sea cannot be considered in absolute terms, since for each floating system, be it a ship, a platform or a buoy, the intensity of the sea state can only be determined in terms of the system's responses. Hence, different thresholds apply to different problems, and sea state 4 may be just as severe for a small patrol craft as sea state 8 may be for a larger containership. Hence, the characteristics and frequency of occurrence of waves in specific sea zones are required if a possible reduction in the system environmental operability is expected.

It is demonstrated that most texts or papers, which deal with the overall question of sea keeping, devote some attention to the basic phenomena, that is, the seaway and the motions of the ship or other floating platforms as a result of the excitation imposed by the seaway. Ship motions, as such, do not always constitute the criteria for sea keeping, and much more often other responses directly related to the magnitude and phasing of the motions or the resulting velocities and accelerations constitute the prime cause for exhibiting good or bad sea keeping qualities. Such responses could be a function of the motion only, as in the case of added resistance or hydrodynamic pressures, or they could be a function of motion and other design parameters, such as freeboard in the case of deck wetness or the longitudinal weight distribution in the case of vertical bending moments.

In this work, latest methods of modeling and computation for body-wave interactions described and compared with data observed for container carrier. The foregoing calculation routine
\end{abstract}


is fairly well accepted today among naval architects specializing in the sea keeping aspects of the ship design process. Differences between the results obtained by various techniques as presented by the available computer programs are insignificant. However, since the regular-wave results are of little or no value except as input for the more realistic long- and short-term response predictions in a real seaway environment, it is important to determine which wave data information and what statistical extrapolation techniques are used to obtain the latter.

The format used to describe the seaway in most ship response calculations is the wave spectrum. However, since measured spectrum for a specific sea zone or route are very rarely available, it is often necessary to use spectrum measured in one location for predictions in another location. In such a case, while the basic spectruml shape and scatter remain unchanged, the percentage of wave height distribution would vary to represent realistic conditions for the sea area in question. Such data usually are based on observations, and assuming the sample is large enough the distribution of expected wave heights should be quite reliable.

An alternative approach often used in ship design is to utilize one of several theoretical spectruml formulations [2, 3, 4] such as the Pierson-Moskowitz one-parameter spectrum, the ISSC spectrum, the JONSWAP spectrum, and other. In each of these cases, some input parameters are required usually in the form of wave height, period, peak frequency, fetch, etc. The reliability of the wave data depends in these cases both on the quality of the input parameter and the adequacy of the theoretical formulation.

Keywords: safety of navigation, seakeeping qualities, analytical modelling, stability assessment.

\section{АННОТАЦІЯ}

У даній роботі зауважено, що конструкція кораблів або будь-яких інших плавучих систем, призначених для експлуатації на поверхні моря або поблизу від неї, значною мірою контролюється збереженням морехідності. Безпека судна, природно, включає екіпаж, вантаж i сам корпус. Підкреслено, що морехідність є досить узагальненим терміном і включає широкий спектр предметів, таких як рухи корабля (амплітуди, прискорення, фази), вологість палуби, плескання, керування хвилями, додатковий опір, гідродинамічні навантаження (тиск, сили, моменти) та перехідні процеси навантаження. Оскільки екологічна придатність судна або його характеристики збереження морехідних якостей тісно пов'язані з важкістю моря, опис морського шляху зазвичай розглядається як невід'ємна частина утримання моря.

Показано, що більшість текстів чи статей, що стосуються загального питання збереження морехідних якостей, приділяють деяку увагу основним явищам, тобто морському шляху та рухам корабля чи інших плавучих платформ в результаті збудження, яке накладає морський шлях. Реакції судна не завжди є критеріями збереження морехідних якостей і набагато частіше інші реакції, безпосередньо пов'язані $з$ величиною і поступовістю рухів, або результуючі швидкості та прискорення складають основну причину демонстрування поганих морехідних якостей. Такі реакції можуть бути функцією лише руху, як у випадку доданого опору або гідродинамічного тиску, або вони можуть бути функцією руху та інших конструктивних параметрів, таких як надводний борт у разі вологості палуби або поздовжнього розподілу ваги в випадок вертикальних згинальних моментів.

Результати аналітичного моделювання та його порівняння із спостережуваними даними показують перспективу суттєвого поліпшення прогнозування якостей морського обслуговування, за умови, що зареєстровані датчиками дані об'єктивних вертикальних прискорень кроку та крену використовуються спільно з обчисленнями. Отримані таким чином оброблені дані можуть стати основою спеціалізованої підтримки та системи прийняття рішень.

Ключові слова: безпека судноплавства, меорехідні якості, аналітичне моделювання, оцінка стійкості. 
Formulation of the problem in general terms and it connection with important scientific practical tasks

The safety of the ship and cargo is associated with negative effects of the wind and waves acting on the ship (rocking, acceleration, slamming, flooding of the deck, propeller emergence). Reducing the impact of these phenomena during the operation of the vessel is associated with speed reduction and/or course changes. Both of these maneuvers will result in elongation of the route and time of shipping, which leads to the increased fuel consumption.

No single parameter can be used to define the sea keeping performance of a design. In a competitive world, a comfortable ship will attract more passengers than a ship with a bad reputation. A ship with less power augment in waves will be able to maintain lighter schedules or will have a lower fuel bill. In extreme cases, the sea keeping qualities of a ship may determine its ability to make a given voyage at all.

Good sea keeping is clearly desirable, but the difficulty lies in determining how far other design features must, or should, be compromised to improve sea keeping. This will depend upon each particular design, but it is essential that the designer has some means of judging the expected performance and effect on the ship's overall effectiveness. Theory, model experiment and ship trial all have a part to play. Because of the random nature of sea surface in which the ship operates, considerable use is made of the principles of statistical analysis.

Having improved the physical response characteristics of a ship in waves the overall effectiveness of a design may be further enhanced by judicious suing of critical activities and by fitting control devices such as anti-roll stabilizers.

As with so many other aspects of ship design a rigorous treatment of sea keeping is very complex and a number of simplifying assumptions are usually made. For instance, the ship is normally assumed to respond to the waves as a rigid body when assessing motions and wetness although its true nature as an elastic body must be taken into account in a study of structure

\section{The last achievements and publications analysis, in which the solution of the problem is begun and selection of the unsolved aspects of the problem}

In [7] a fully coupled model of nonlinear sloshing and ship motion was developed. The fully nonlinear sloshing motion was studied using a FE method, potential flow, and the nonlinear ship motion was simulated using a hybrid marine control system. Simulated roll motions were compared with existing results in waves. Fair agreement indicated that the proposed model was expected to be useful in evaluating the coupling effect. In their study, the coupling model also allowed for the effects of wind, wave and current. It was found that the wave height can have large effects on sloshing, whereas the current velocities caused fairly marginal effects on the ship motions.

In work [8] a numerical seakeeping-sloshing coupling analysis carried out for an 8,000 TEU container ship with some cargo holds partially ballasted, with sea water, to simulate a full load condition, to design draft, required in sea trials. A frequency domain model is utilized in the hydrodynamic numerical code HydroSTAR considering high speed effect, and the analysis includes nonlinear seakeeping, linear sloshing and finally the calculation of the coupled equations of motion. The additional resonant frequencies, especially for the rolling motions, induced by the motionsloshing coupling effect are clarified and their corresponding operational scatter diagrams, for heading direction change based on specific sea state, are provided. The results confirmed that the induced resonant frequency will occur with full load condition and full ship speed, especially for rolling motion, and may cause serious structural problems.

The multi-liquid moving particle semi-implicit (MPS) method developed in [9]. The developed multi-liquid MPS method is validated by comparison with three liquid-sloshing experiments by [10]. The interfacial natural frequencies are simulated by a free decay test using the MPS program and the results are compared with linear potential theory. The simulated results agree well against both experimental and theoretical values. The authors observed that the interfacial elevations can significantly increase when the excitation frequency is close to the natural frequencies of the respective interfaces. Subsequently the verified multi-liquid MPS program is 
coupled to a vessel motion program in time domain. From the numerical simulations, the authors noted that the wash tank operation in head wave condition is much more robust than that in beam wave condition. The vessel motions with the three-liquid cargo and the corresponding solid cargo were also compared, and it was observed that the wash tank with liquid cargo can also function as a beneficial anti-rolling device. Based on these comparisons it was concluded that the simple approximation using equivalent rigid cargo and ignoring coupling with liquid sloshing can be unreliable in the design stage. Since maximum vessel motions and maximum interface elevations can be checked directly, the developed vessel motion/multi-liquid-sloshing coupled program can be used as a reliable prediction tool for the safety and operability of a floating system with large multiliquid tanks.

\section{The paper purpose formulation}

In this work demonstrated the perspective of significant improvement in seakeeping qualities prediction, provided that registered by sensors objective vertical accelerations data of pitch and roll is used in conjunction with computations. Processed data obtained in this way can become a basis of specialized support and decision-making system.

\section{Presentation of basic research material substantiating scientific results}

\section{Ship motion and added resistance modelling}

For comparison with observational data it is necessary to perform a theoretical estimation of statistical characteristics of the behavior of the vessel. The basis for such assessments in accordance with the accepted approach is the calculation of dispersion processes caused by the ship's motion, as well as assessment of vessel speed loss at various heading angles in relation to general direction of waves.

Six motion components are considered for ship with constant speed V and arbitrary heading angle relative to oncoming waves.

Motion components are: linear $\eta_{1}-$ surge, $\eta_{2}-$ sway, $\eta_{3}-$ heave; angular $\eta_{4}-$ roll, $\eta_{5}-$ pitch, $\eta_{6}-$ yaw.

Motion is presented in form:

$$
\eta_{j}=a_{j} \cos \left(\omega_{e} t-\varepsilon_{j}\right), j=1, \cdots, 6
$$

where $a_{j}$-amplitude of the relevant type of motion; $\omega_{e}=\omega-\frac{\omega^{2} \mathrm{~V}}{\mathrm{~g}} \cos \mu-$ frequency of encounter; $\omega=\sqrt{\frac{2 \pi}{\lambda} g}$ - wave frequency; $\lambda$ - wave length; $g$ - gravity acceleration; $\varepsilon_{\mathrm{j}}$ - phase lag of motion relative to the maximum wave profile at the origin; $\mu$ - heading angle.

The problem is solved with the usual assumptions of the linear theory (including non-linear roll damping) using well known strip method.

The system of six linear differential equations of motion expressed as follows:

$$
\sum_{j=1, k=1}^{6}\left[\left(M_{j, k}+A_{j, k}\right) \ddot{\eta}_{k}+B_{j, k} \dot{\eta}_{k}+C_{j, k} \eta_{k}\right]=F_{j} e^{-i \omega_{e} t}, j=1, \cdots, 6
$$

where $\mathrm{M}_{\mathrm{j}, \mathrm{k}}$ - mass matrix of the vessel; $\mathrm{A}_{\mathrm{j}, \mathrm{k}}$ and $\mathrm{B}_{\mathrm{j}, \mathrm{k}}$ - added mass and damping coefficients matrix; $\mathrm{C}_{\mathrm{j}, \mathrm{k}}$ - restoring forces coefficients; $\mathrm{F}_{\mathrm{j}}$ - complex amplitudes of exited forces and moments; $\dot{\eta}_{\mathrm{k}}, \ddot{\eta}_{\mathrm{k}}$ - the velocity and acceleration of each type of motion, $\mathrm{k}=1, \cdots, 6$, (point above the symbol denotes the time differentiation); $\mathrm{i}$ - imaginary unit.

Mass matrix for vessel symmetric to fore and aft line has the form: 


$$
\left[\mathrm{M}_{\mathrm{j}, \mathrm{k}}\right]=\left[\begin{array}{cccccc}
\mathrm{M} & 0 & 0 & 0 & \mathrm{Mz}_{\mathrm{g}} & 0 \\
0 & \mathrm{M} & 0 & -\mathrm{Mz}_{\mathrm{g}} & 0 & 0 \\
0 & 0 & \mathrm{M} & 0 & 0 & 0 \\
0 & -\mathrm{Mz}_{\mathrm{g}} & 0 & \mathrm{I}_{4} & 0 & -\mathrm{I}_{46} \\
\mathrm{Mz}_{\mathrm{g}} & 0 & 0 & 0 & \mathrm{I}_{5} & 0 \\
0 & 0 & 0 & -\mathrm{I}_{46} & 0 & \mathrm{I}_{6}
\end{array}\right]
$$

where M-ship`s mass; $I_{j}$ - moment of inertia $\mathbf{j}$-type; $I_{j k}$ - centrifugal moment of inertia.

Centrifugal moment of inertia in (1.3) becomes zero if there is a symmetry with respect to the midsection and is minor in other cases.

The matrix of added masses (or damping) has the form:

$$
\left[A_{j, k}\right]=\left[\begin{array}{cccccc}
A_{11} & 0 & A_{13} & 0 & A_{15} & 0 \\
0 & A_{22} & 0 & A_{24} & 0 & A_{26} \\
A_{31} & 0 & A_{33} & 0 & 0 & 0 \\
0 & A_{42} & 0 & A_{44} & 0 & A_{46} \\
A_{51} & 0 & A_{53} & 0 & A_{55} & 0 \\
0 & A_{26} & 0 & A_{46} & 0 & A_{66}
\end{array}\right] .
$$

Non-zero are the following restoring forces coefficients:

$$
\mathrm{C}_{33}, \mathrm{C}_{44}, \mathrm{C}_{55}, \mathrm{C}_{35}=\mathrm{C}_{53}
$$

With regard to (1.3), (1.4) and (1.5) the system (1.2) roll equations splits into two systems. The first - the system of differential equations of longitudinal motion:

$$
\begin{gathered}
\left(A_{11}+M\right) \ddot{\eta}_{1}+B_{11} \dot{\eta}_{1}+A_{13} \ddot{\eta}_{3}+B_{13} \dot{\eta}_{3}+\left(A_{15}+M z_{g}\right) \ddot{\eta}_{5}+B_{15} \dot{\eta}_{5}=F_{1} e^{-i \omega_{\theta} t}{ }_{5} \\
A_{31} \ddot{\eta}_{1}+B_{31} \dot{\eta}_{1}+\left(A_{33}+M\right) \ddot{\eta}_{3}+B_{33} \dot{\eta}_{3}+C_{33} \eta_{3}+A_{35} \ddot{\eta}_{5}+B_{35} \dot{\eta}_{5}+C_{35} \eta_{5}=F_{3} e^{-i \omega_{\theta} t} ; \\
\left(A_{51}+M z_{g}\right) \ddot{\eta}_{1}+B_{51} \dot{\eta}_{1}+A_{53} \ddot{\eta}_{3}+B_{53} \dot{\eta}_{3}+\left(A_{55}+I_{5}\right) \ddot{\eta}_{5}+B_{55} \dot{\eta}_{5}+C_{55} \eta_{5}=F_{5} e^{-i \omega_{8} t} ;
\end{gathered}
$$

and a system of describing transverse motion and yawing:

$$
\begin{gathered}
\left(A_{22}+M\right) \ddot{\eta}_{2}+B_{22} \dot{\eta}_{2}+\left(A_{24}-M z_{g}\right) \ddot{\eta}_{4}+B_{24} \dot{\eta}_{4}+C_{44} \eta_{4}+A_{26} \ddot{\eta}_{6}+B_{26} \dot{\eta}_{6}=F_{2} e^{-i \omega_{\theta} t} \\
\left(A_{24}-M z_{g}\right) \ddot{\eta}_{2}+B_{24} \dot{\eta}_{2}+\left(A_{44}+I_{4}\right) \ddot{\eta}_{4}+\left(B_{44}+B_{44}^{t}\right) \dot{\eta}_{4}+C_{44} \eta_{4}+\left(A_{46}-I_{46}\right) \ddot{\eta}_{6}+B_{46} \dot{\eta}_{6} \\
=F_{4} e^{-i \omega_{g} t} \\
A_{62} \ddot{\eta}_{2}+B_{62} \dot{\eta}_{2}+\left(A_{64}-I_{46}\right) \ddot{\eta}_{4}+B_{64} \dot{\eta}_{4}+\left(A_{66}+I_{6}\right) \ddot{\eta}_{6}+B_{66} \dot{\eta}_{6}=F_{6} e^{-i \omega_{g} t}
\end{gathered}
$$

Dispersion of processes were calculated by the known formula:

$$
\mathrm{D}=\int_{0}^{\infty}\left|\mathrm{a}_{\mathrm{j}}\left(\omega_{\mathrm{e}}\right)\right|^{2} \mathrm{~S}_{\zeta}\left(\omega_{\mathrm{e}}\right) \mathrm{d} \omega_{\mathrm{e}},
$$

where $\left|\mathrm{a}_{\mathrm{j}}\left(\omega_{\mathrm{e}}\right)\right|$ - module of amplitude-frequency characteristics of the process; $\mathrm{S}_{\boldsymbol{Z}}\left(\omega_{\mathrm{e}}\right)$ - sea waves spectruml density; $\omega_{e}-$ frequency of encounter.

Average added resistance in irregular waves is given by:

$$
\overline{\mathrm{R}}_{\mathrm{AW}}=2 \int_{0}^{\infty} \mathrm{r}_{\mathrm{AW}}\left(\omega_{\mathrm{e}}\right) \mathrm{S}_{\zeta}\left(\omega_{\mathrm{e}}\right) \mathrm{d} \omega_{\mathrm{e}},
$$

where $r_{A W}=R_{A W}\left(\omega_{e}\right) / \zeta_{\mathrm{a}}^{2}$ - the average additional resistance when driving on a regular excitement unit with an apparent amplitude frequency $\omega_{\mathrm{e}} ; \zeta_{\mathrm{a}}-$ regular wave amplitude. 
In the present calculations, the resistance on calm water was determined by the Holtrop method; air resistance - by Isherwood method; added resistance on a regular waves was evaluated by Gerritsma method:

$$
R_{A W}=\frac{k}{2 \omega_{e}} \int_{0}^{L} b_{33}(x) V_{z r}^{2}(x) d x
$$

where $k$ - wave number; $b_{33}(x)$ - damping coefficient of the cross section due to vertical motion; $\mathrm{V}_{\mathrm{zr}}(\mathrm{x})$ - section vertical velocity with respect to the wave profile.

\section{Assessment of ships propulsion}

At the first stage in determining seakeeping qualities, preliminary assessment of ship propulsion in loaded condition in calm sea was carried out. Towing resistance within a speed range from 1 to 20 knots was calculated by Holtrop method. Propeller trust in nominal mode of engine within same speed range was assessed by calculations.

The calculations assumed that the hull is freshly painted, and the engine power fully corresponds to the nameplate data.

Further calculations were performed to assess the speed loss in rough seas due to the medium resistance and characteristics of the main engine. Speed drop determination is based on the condition of equation between propeller thrust and medium resistance to ships motion:

$$
T\left(V_{s}\right)=R\left(V_{s}\right)+R_{a}\left(V_{s}, V_{a}\right)+h_{3 \%}^{2} \bar{r}_{A W}\left(V_{s}\right),
$$

where $T$ - propeller thrust; $R$ - towing resistance in calm sea; $R_{a}$ - air resistance; $\bar{r}_{A W}$ - mean added resistance in irregular waves of the unit height $\left(h_{3 \%}=1.0 \mathrm{~m}\right) ; V_{s}$ - ships speed; $V_{a}$ - wind speed.

Air resistance is determined by:

$$
R_{a}=\frac{1}{2} C_{X} \rho_{a} F_{T} V_{a}^{* 2},
$$

where $C_{X}$ - air resistance coefficient; $\rho_{a}$ - air density; $V_{a}^{*}$ - true wind speed.

Calculations of air resistance coefficients performed by the method of Isherwood [2]. As shown by calculations, the greatest value of $C_{X}$ corresponds to the angle between vectors of ships and wind speed $30^{\circ}$ (head wind is $0^{\circ}$ ). The greatest computational values of the coefficient $C_{X}$ within the range from $0^{\circ}$ to $40^{\circ}$ vary from 0.55 to 0.81 .

Air resistance is determined by frontal projection of the sail area and for various combinations of wind force and wave intensity, as well as ships speed varies from an average of $3 \mathrm{kN}$ on a wave intensity 2 points to $12 \mathrm{kN}$ on an intensity of 7 points, which is about $2 \%$ and $10 \%$ of resistance in calm sea with the engine running at nominal power.

Taking into account relatively high value of sail area (ratio $F_{T} / \Delta^{2 / 3}$ Further, in these calculations, to simplify assessment, assumed that $R_{a}=0.1 R$.

Calculation results of ships added resistance when moving at regular head waves as a function of dimensionless added resistance coefficient $\sigma_{A W}=\frac{R_{A W}}{\rho g \zeta_{a}^{2} B^{2} / L}$ and dimensionless encountered frequency $\bar{\omega}_{e}=\omega_{e} \sqrt{L / g}$. Required value of damping coefficients and added mass, as well as kinematical characteristics were determined using the software system, consisting of a complex of programs.

Details of calculations of motion parameters and kinematical characteristics described in detail in the work.

In this way for given value of speed the respective wave height can be determined by formula: 


$$
h_{3 \%}=\sqrt{\frac{T-R-R_{a}}{\bar{r}_{A W}}}
$$

For calculated wave spectrum was taken spectrum of the II International Congress on the hull strength and design. Calculation of speed loss at head irregular two-dimensional waves is shown in Fig. 1.1.

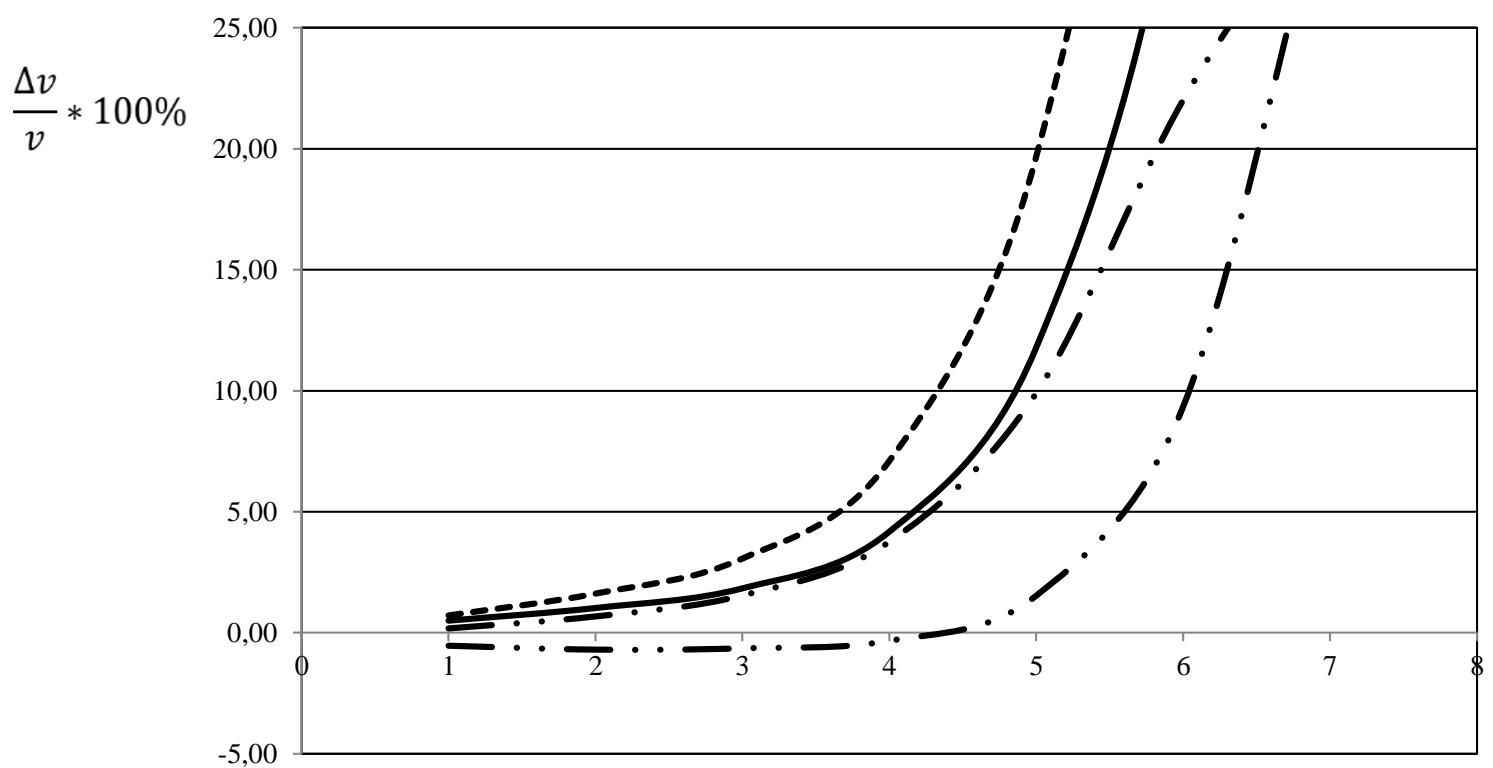

Beaufort Number

solid line - averaged heading

drop line - head seas

upper dash-dot - beam seas

Figure 1. Speed loss in irregular seas (full load)

Analysis of received results indicates that in the entire range of average periods from 9 to $9 \mathrm{~s}$ with wave intensity up to 6 points, speed loss occurs quite smoothly and is about $5 \%$. At wave intensity of more than 6 points and the average wave period more than 7 seconds, ship's speed loss is more prominent. With the increase of the average period, the speed loss becomes less prominent, due to below-resonant and less intensive pitching. Assessing the results of calculations of ship propulsion under real operating conditions, it should be borne in mind that adopted mode of purely head irregular two-dimensional waves is rather rigid and overestimates the speed drop. The fact that the real sea waves are three-dimensional, rather than two-dimensional, also indicates an overestimation in the calculated speed loss.

Considering above circumstances, it can be assumed that the value of the achievable speed of the vessel in rough seas with intensity $4-6$ points can be about 18 knots. Thus, the speed 8 knots, with an error in a safe direction, can be taken in the assessment of the characteristics of extreme roll parameters and seakeeping characteristics - dangerous vertical acceleration, slamming, green water effect and propeller racing.

\section{Statistical seakeeping characteristics}

In this work following seakeeping characteristics were assessed: probability of taken dangerous vertical accelerations, slamming, green water and propeller racing. Under dangerous acceleration is understood exceeding of value of vertical acceleration more than $0.4 \mathrm{~g}$ at the forward perpendicular. Dangerous green water refers to the water level exceeding the height of freeboard. Slamming is a phenomenon consisting of the bottom being exposed from water in the section frame №3 and its further entry into the water with speed exceeding a certain threshold value $V^{*}$. Propeller racing is exposure of the propeller blades from the water of more than $1 / 3$ of the diameter.

Thus, above mentioned seakeeping characteristics are determined as following kinematical characteristics: vertical accelerations - standard of vertical accelerations at forward perpendicular; 
green water - standard of relative motion at the forward perpendicular; slamming - standards of relative motions and speed in the section frame №3; propeller racing - standard of relative motions in the section on the propeller.

According to [4] limiting values provided probabilities of these effects:

$\begin{array}{lll}\text { vertical accelerations } & -13.5 \% & \left(p_{A}=0.135\right) ; \\ \text { green water } & -7 \% & \left(p_{d w}=0.07\right) ; \\ \text { slamming } & -3 \% & \left(p_{s l}=0.03\right) ; \\ \text { propeller racing } & -25 \% & \left(p_{p r}=0.25\right) .\end{array}$

The threshold value of speed of the relative vertical motion according to the recommendations [11]:

$$
V^{*}=0.0928 \frac{0.6}{C_{b}} \sqrt{L g},
$$

where $C_{b}-$ block coefficient.

In the calculations of green water the effective freeboard means geometric freeboard without the correction for the distortion of the wave profile (a running wave). The value of the latter was taken according to the recommendations for marine vessels / $11 /$.

Assuming that roll processes amplitudes distributed by the law of Relay received the following formulas for marginal wave heights, at which probability of respective effects is acceptable:

- for vertical accelerations

$$
h=\frac{0.4 g}{\overline{\sigma_{A}} \sqrt{2 \ln \left(1 / p_{A}\right)}},
$$

where $\overline{\sigma_{A}}-$ standard of vertical accelerations at forward perpendicular $h_{3 \%}=1 \mathrm{~m}$;

- for green water effect

$$
h=\frac{F_{e}}{\overline{\sigma_{r 0}} \sqrt{2 \ln \left(1 / p_{d w}\right)}},
$$

where $\overline{\sigma_{r 0}}-$ standard of relative motion at the forward perpendicular $h_{3 \%}=1 \mathrm{~m}$;

- for slamming

$$
h=\sqrt{\frac{V^{* 2} / \bar{\sigma}_{r 3}^{2}+d_{3}^{2} / \bar{\sigma}_{V r 3}^{2}}{2 \ln \left(1 / p_{s l}\right)}},
$$

where $\bar{\sigma}_{r 3}, \bar{\sigma}_{v r 3}$ and $d_{3}$-standard of relative motion at the forward, relative vertical speed and draft in the section frame №3 with $h_{3 \%}=1 \mathrm{~m}$;

- for propeller racing

$$
h=\frac{H_{p r}}{\bar{\sigma}_{r p r} \sqrt{2 \ln \left(1 / p_{p r}\right)},}
$$

where $H_{p r}, \bar{\sigma}_{r p r}$ - penetration of the upper edge of the blade and standard of the relative vertical motions in the section on the propeller $h_{3 \%}=1 \mathrm{~m}$; 
The results of calculations of limiting seakeeping criteria wave heights produced by the above dependencies, for loaded ship are shown in Table. 4.1.

Analysis of seakeeping characteristics for loaded ship demonstrates the absence of restrictions on dangerous accelerations, green water, slamming and propeller racing at wave intensity of 6 points or higher on Beaufort Scale. The speed drop in rough seas is completely determined by its natural decline, arising from increased resistance.

Table 4.1 Allowable wave heights for loaded ship with draft $9,36 \mathrm{~m}$

\begin{tabular}{|c|c|c|c|c|c|c|c|c|c|c|}
\hline \multirow{2}{*}{\begin{tabular}{c} 
Mean $\begin{array}{c}\text { period } \\
\tau, \mathrm{c}\end{array}$ \\
\cline { 2 - 10 }
\end{tabular}} & 0 & 30 & 45 & 60 & 90 & 120 & 135 & 150 & 180 \\
\hline 4 & 22.5 & 18.4 & 15.7 & 13.7 & 11.5 & 11.2 & 11.7 & 12.4 & 13.4 \\
\hline 5 & 18.7 & 15.6 & 13.4 & 11.6 & 9.3 & 8.6 & 8.6 & 8.8 & 9.1 \\
\hline 6 & 17.9 & 15.6 & 13.7 & 12.0 & 9.6 & 8.5 & 8.4 & 8.4 & 8.4 \\
\hline 7 & 18.7 & 16.8 & 15.2 & 13.5 & 10.8 & 9.4 & 9.1 & 9.0 & 8.9 \\
\hline \multicolumn{10}{|c|}{ under green water condition } \\
\hline 4 & 8.98 & 8.94 & 8.87 & 8.72 & 8.23 & 7.77 & 7.63 & 7.55 & 7.48 \\
\hline 5 & 7.87 & 8.04 & 8.18 & 8.22 & 7.70 & 6.84 & 6.50 & 6.24 & 6.03 \\
\hline 6 & 7.89 & 8.22 & 8.55 & 8.81 & 8.36 & 7.10 & 6.58 & 6.19 & 5.88 \\
\hline 7 & 8.59 & 9.06 & 9.57 & 10.05 & 9.67 & 7.99 & 7.28 & 6.77 & 6.37 \\
\hline \multicolumn{8}{|c|}{ under slamming condition } \\
\hline 4 & 9.89 & 9.90 & 9.86 & 9.74 & 9.24 & 8.77 & 8.64 & 8.58 & 8.55 \\
\hline 5 & 10.61 & 10.77 & 10.85 & 10.76 & 9.92 & 8.90 & 8.54 & 8.31 & 8.12 \\
\hline 6 & 12.26 & 12.59 & 12.85 & 12.87 & 11.73 & 10.12 & 9.53 & 9.13 & 8.80 \\
\hline 7 & 14.64 & 15.16 & 15.62 & 15.76 & 14.31 & 12.06 & 11.22 & 10.64 & 10.18 \\
\hline \multicolumn{8}{|c|}{ under racing propeller condition } \\
\hline 4 & 10.47 & 9.42 & 9.10 & 9.96 & 9.07 & 9.59 & 9.85 & 10.03 & 10.14 \\
\hline 5 & 10.14 & 9.28 & 9.03 & 5.91 & 9.06 & 9.58 & 9.85 & 10.04 & 10.17 \\
\hline 6 & 10.52 & 9.79 & 9.64 & 9.61 & 9.86 & 10.36 & 10.56 & 10.65 & 10.66 \\
\hline 7 & 11.40 & 10.75 & 10.69 & 10.76 & 11.18 & 11.66 & 11.76 & 11.72 & 11.54 \\
\hline
\end{tabular}

\section{Conclusions}

Performed complex assessment of the seakeeping of the observed vessel at waves intensity up to 8 points on Beaufort scale. The calculation results demonstrates that at waves intensity up to 6 points in the entire range of average periods from 7 to $18 \mathrm{~s}$, speed drop is quite smooth about 5 $15 \%$.

At head waves intensity of more than 6 points, and the average period more than 12 seconds, the ship's speed drops significantly. With the increase of the average period, the speed loss becomes less prominent, due to below-resonant and less intensive pitching.

Analysis of seakeeping characteristics for loaded ship demonstrates the absence of restrictions on dangerous accelerations, green water, slamming and propeller racing at wave intensity up to 6 points or higher on Beaufort Scale. The speed loss in rough seas is completely determined by its natural reduction due to resistance increase. Results of presented calculations demonstrate the possibility of operation of the vessel with draft of $9,36 \mathrm{~m}$ at the wave heights of three percent probability up to $11 \mathrm{~m}$.

Based on performed observations and analytical modeling, it can be concluded that ship's behavior under storm conditions qualitatively agrees with the results of the executed calculations. Seakeeping characteristics such as slamming, dangerous accelerations, green water and propeller racing do not exceed marginal values. Calculation of speed loss, based on statistical dependences, indicates that computational results, in general, quite agree with observed statistical characteristics. 
Computations at irregular waves demonstrate that speed loss significantly depends on actual engine power. Present statistical dependences do not take into account this important fact.

The results of analytical modelling and its comparison with data observed, show the perspective of significant improvement in seakeeping qualities prediction, provided that registered by sensors objective vertical accelerations data of pitch and roll is used in conjunction with computations. Processed data obtained in this way can become a basis of specialized support and decision-making system.

\section{REFERENCES}

1. Rawson K. J., Tupper E. C. Basic Ship Theory / Vol.1 \& 2, 2001 - pp. 731.

2. DNV-RP-C205 Environmental conditions and environmental loads / DNV - Norway, April 2007. - pp. 122.

3. ARJM Lloyd Seakeeping: Ship behaviour in rough weather / UK, 1998 - pp. 395.

4. ISSC committee I.2: Loads / Cassias, Portugal, 7-10 September 2015. - pp. 55.

5. Bowditch N. The American Practical Navigator. Bicentennial Edition / N. Bowditch // National Imaginary and Mapping Agency, USA. 2002. - 877 p.

6. 68. Buckens K. Ship dynamics and rolling / K. Buckens // Seaways: The Interna-tional Journal of the NI., Apr 2005 - pp. 13-14.

7. Mitra, S., Wang, C., Reddy, J. \& Khoo, B. 2012. A 3d fully coupled analysis of nonlinear sloshing and ship motion. Ocean Engineering 39, 1-13. Wiśniewski B.: Ship route optimization taking into account weather conditions, Wyższa Szkołą Morska w Szczecinie, Szczecin 1986.

8. Tsai, S. C., Hsu, S. H., Chien, H. L., Chou, C. M., Malenica, M. \& Chen, X. B. 2013. Numerical study on seakeeping-sloshing coupling effect of container ship for sea trial purpose. In Proc. 12th Int. Symp. on Practical Design of Ships and Other Floating Structures PRADS, Changwon, Korea.

9. Kim, Y. \& Park, S. G. 2014. Wet damping estimation of the scaled segmented hull model using the random dec-rement technique. Ocean Engineering 75, 71-80.

10. Molin, B., Remy, F., Audiffren, C. \& Marcer, R. 2012. Experimental and numerical study of liquid sloshing in a rectangular tank with three fluids. In Proc. 22nd Int. Offshore and Polar Engineering Conference ISOPE, Rhodes, Greece.

11. Wiśniewski B., Medyna P., Klein R., Jakubowski M.: The application of weather forecasts and average climate conditions in assessing routes for ships sailing with different operating speeds on the northern Atlantic, EXPLO-SHIP 2002, Zeszyty Naukowe nr 65, WyższaSzkoła Morska, 2002.

12. Tadeusz Szelangiewicz, Bernard Wiśniewski, Katarzyna Żelazny, Maritime University of Szczecin, West Pomeranian University of Technology: POLISH MARITIME RESEARCH 3(83) 2014 Vol. 21; pp. 61-67 